\section{Chatham House (Royal Institute of International Affairs)}

Founded 1920. Leading independent think tank whose research centres on three areas: energy, environment and resource governance; international economics; regional and security studies. Established the 'Chatham House Rule' that aids free and open debate by allowing for anonymity of speakers at meetings. Sister organization of Council on Foreign Relations in New York.

Address: 10 St James's Square, London, SW1Y 4LE, UK.

Website: http://www.chathamhouse.org

Director: Dr Robin Niblett.

\section{China Institute of International Studies (CIIS)}

Founded 1956. The think tank of China's ministry of foreign affairs focuses on global politics and economics and the decisionmaking process of the central government. Research at the Institute centres on medium and long-term policy issues of strategic importance, specifically those concerning international politics and the world economy.

Address: 3 Toutiao, Taijichang, Beijing 100005, China.

Website: http://www.ciis.org.cn

President: Qi Zhenhong.

\section{China Institutes of Contemporary International Relations}

Founded 1965. Influential research institution of international studies devoted to a wide range of political, economic, diplomatic, military and social issues spanning all continents as well as issues related to Hong Kong, Macao and Taiwan. A key research area is the United States and the Sino-US relationship.

Address: A-2 Wanshousi, Haidian District, Beijing 100081, China.

Website (Chinese only): http://www.cicir.ac.cn

President: Ji Zhiye.

\section{Chinese Academy of Social Sciences}

Founded 1977. China's highest academic research organization in the fields of philosophy and social sciences. Comprises 32 research institutes, three research centres and a graduate school. Research covers 120 key areas.

Address: 5 Jianguomennei Dajie, Beijing 100732, China.

Website: http://cass.cssn.cn

President: Wang Weiguang.

\section{Council on Foreign Relations}

Founded 1921. Independent think tank that seeks to foster better understanding of the world and the foreign policy choices facing the USA and other countries. Research by the David Rockefeller Studies Program centres on major geopolitical areas but also covers global health, international institutions and global governance, national security, science and technology and US foreign policy. Sister organization of Chatham House in London.

Address: The Harold Pratt House, 58 East 68th St., New York, NY 10065, USA.

Website: http://www.cfr.org

Board of Directors Chairs: Carla A. Hills; Robert E. Rubin.

President: Richard N. Haass.

\section{Danish Institute for International Studies}

Founded 2002 by the Danish parliament. Independent institution engaged in research in international affairs in order to assess the security and foreign policy situation of Denmark. Research units: defence and security; foreign policy and EU studies; global economy, regulation and development; holocaust and genocide; migration; natural resources and poverty; politics and governance; the Middle East.

Address: Østbanegade 117, 2100 Copenhagen, Denmark.

Website: http://www.diis.dk

Chairman of the Board: Johnny Laursen.

\section{European Council on Foreign Relations}

Founded 2007. Pan-European think tank that conducts European foreign policy research and promotes a more integrated European foreign policy in support of shared European interests and values. Main programmes: Russia and wider Europe; China; democracy, human rights and the rule of law.

Address: 4th Floor, Tennyson House, 159-165 Great Portland St., London, W1W 5PA, UK.

Website: http://www.ecfr.eu

Director: Mark Leonard.

\section{Fraser Institute}

Founded 1974. Independent non-partisan research and educational organization that aims to measure, study and communicate the impact of competitive markets and government interventions on the welfare of individuals. Research covers taxation, government spending, health care, school performance and trade.

\author{
Address: 4th Floor, 1770 Burrard St., Vancouver, BC, Canada \\ V6J 3 G7. \\ Website: http://www.fraserinstitute.org \\ President: Niels Veldhuis.
}

\section{French Institute of International Relations (IFRI)}

Founded 1979. The Institut Français des Relations Internationales is an independent research and debate institution dedicated to international affairs. Research centres on geographic regions as well as economy; energy; Franco-German relations; health/ environment; migration; identities and citizenship; security and defence; space; and sport.

Address: 27 rue de la Procession, 75740 Paris Cedex 15, France. Website: http://www.ifri.org

President: Thierry de Montbrial.

\section{Friedrich Ebert Foundation (Friedrich-Ebert-Stiftung; FES)}

Founded in 1925 as a political legacy of Germany's first democratically elected president, Friedrich Ebert. Non-profit foundation committed to the advancement of public policy issues in the spirit of the basic values of social democracy. Focuses on democracy promotion and international dialogue on the central topics of international politics, globalization, and economic, social and political development in the world.

Address: Berliner Haus, Hiroshimastrasse 17, 10785 Berlin, Germany; Bonner Haus, Godesberger Allee 149, 53175 Bonn, Germany.

Website (German only): http://www.fes.de

Chairman: Kurt Beck. 